\title{
Strategies in Peace Education and National Cohesion: The Nigeria Perspective
}

\author{
Dr. Ofoego Chinyere .O. \\ Department Of Educational Foundations/Administration, \\ Alvan Ikoku Federal College Of Education, Owerri.Imo State, Nigeria. \\ Dr Charles .N. Ugwuegbulam \\ Department Of Educational Psychology/Counselling \\ Alvan Ikoku Federal College Of Education, Owerri, Imo State, Nigeria.
}

\begin{abstract}
Despite well-intended efforts by Nigeria governments past and present towards national integration, Nigeria's unity has continued to be plagued and threatened by conflicts and violence. This paper is of the view that perhaps emphasis should be directed towards more effective ways of cultivating the culture of peace among Nigerians. The paper therefore critically examined the various strategies and platforms already put in place in Nigeria for developing the skills and attitudes necessary for peaceful coexistence in the country. The success and failures of these strategies were discussed and suggestions on improving their effectiveness were made.
\end{abstract}

Keywords: Conflict, Violence, Peace, Peace education.

DOI: $10.7176 / \mathrm{JEP} / 11-6-21$

Publication date: February $29^{\text {th }} 2020$

\section{Introduction}

Peace is a priceless attribute of every human society. It is a global value that is highly cherished as no nation can hardly develop without peace. This is why efforts are locally and internationally made to ensure that an environment devoid of violence, crises and war is guaranteed. Nigeria) is a peace loving country that believes in unity and world peace. This is why the overall philosophy of Nigeria as stipulated in the National policy on Education are to; (a) live in unity and harmony as one indivisible, indissoluble, democratic and sovereign nation founded on the principles of freedom, equality and justice; (b) promote inter-African solidarity and world peace through understanding.

From the foregoing policy statements, it is evident that Nigeria wishes to live together in peace internally and with her neighbours. In the same way, the attainment of these objectives could lead to the entrenchment of peace and unity in Nigeria. It is however, unfortunate that all these hopes seem to have eluded the nation as Salisu and Sadiq, (2013) have averred that Nigeria has witnessed numerous conflicts since independence. Nigeria has also been bedeviled with serious sectarian, ethno-religious, regional, ethnic, political and other primordial differences and conflicts. This situation they opined, has further been escalated by the rise and existence of ethnic militant agitations, unequal relations, manipulation by elites and political class, excessive riches amidst abject poverty, unemployment, violation of human rights, aggressive tendencies, violence and many more.

The series of conflicts and crises witnessed in the country for decades now have so far retarded Nigeria's efforts at achieving peace, unity and developing economically. In this direction, Osaat, Orlukwu, and lyleka-Jaja, (2018) have noted with regrets that all programmes and efforts made by various governments in Nigeria to ensure that peace and unity reigns by way of peace education, peace keeping and peace building are not enough as more devastating violence rocks the nation on daily basis. This paper therefore, sets out to discuss and analyse the various strategies in peace education the Nigerian government has used to entrench peaceful coexistence in Nigeria. The effectiveness and short falls of these strategies would be also highlighted. This has become imperative because the absence of peace and unity in the country has brought about violent conflicts, bloodshed, pain, untold suffering, hardship, and death of many in Nigeria.

\section{Conceptual Clarification Concept of Conflict}

Conflict can be seen as a product of clash of interest between those involved in some form of relationship. It can take the form of occasional frictions and bickering leading to misunderstanding. There is a general agreement among scholars that conflict is a normal phenomenon in human relationship. As Salisu and Sadiq (2013) have noted, it is not restricted to any particular level and can occur within a family and between families, within community and between communities, within a country and between countries and within an organization and between organizations. In this regard, Chandra, (2016) avers that conflict is part of life and its nature. For him, conflict is not the same as violence, conflict is inevitable in human nature but violence is not.

Explaining conflict from another perspective, Thomas, (1992) in Robbins, and Judge, (2010) argues that 
conflict is a process that begins when one party or group perceives that another party or group has negatively affected or is about to negatively affect something that the first party cares about. From the views expressed above, conflict can arise in virtually any social setting, be it between or within individuals, groups, communities, tribes, states or nations. Kreitner and Kinick,(2010) have discussed the views of two conflicting schools of management on violence. One school views conflict as a dysfunctional outcome that threatens social harmony, peaceful coexistence and economic growth and development and as such it is harmful and should be avoided as it has a negative connotation. To them, it is synonymous with such terms as violence, destruction and irrationality. Schools with this perception treat conflict as a negative pathological condition characterized by hostility, struggle, breakdown of law, order, rules and regulations, lack of cooperation etc.

Another school of management thought posits that conflict is a functional outcome and argues that it is natural and inevitable in all social settings, endeavours and organizations, and has the potential to be a positive force in determining and fostering community harmony, peaceful existence and national development. This perception sees conflict as not only inevitable but necessary in our social life and treats it as a means that addresses issues like marginalization, exploitation, injustice, abuse of power and resources (Kreitner, and Kinicki, 2010). The views expressed above indicate that although conflict can be a serious problem if it is allowed to escalate, as it could create chaotic conditions that make it impossible for people to relate or live together peacefully. There is also the belief that it strengthens equity and fairness, social interaction, economic growth and development.

Ghandi (2016) has noted some general root causes of conflicts as;

- $\quad$ Competition for the same resources such as territory, jobs, income, housing.

- Where sharing of resources is not fair or is not enough to go round.

- Dissatisfaction on the way leaders govern.

- $\quad$ Clash of beliefs for instance by religious groups.

- $\quad$ Greed by many of our leaders, representatives.

- $\quad$ Operation and marginalization of a group or groups of people.

In Nigeria situation, it is a country characterized by diversity; it is a multi-ethnic, multi-religious, multi lingual nation with several divergent cultures. In such a diverse society, there would likely exist occasional misunderstanding and conflict (Salisu and Sadiq, 2013). Nigeria has indeed had her fair share of conflicts in the past and the present day for example, Fulani herders/farmers clashes and Boko Haram attacks. It thus becomes imperative that for Nigeria to develop and to remain one sovereign nation, she must articulate and adopt effective strategies for peace via peace education.

\section{Concept of Violence}

Most scholars are of the view that conflict usually reflects a clash of interest or goal between parties, individuals or groups of individuals, or ethnic groups or states. According to Oxford Learners Dictionary, violence is a behaviour that is intended to injure or kill people, by hitting them or shooting them. Obasi, (2013) has noted that violence which is any action involving the use of force with the intention to harm, damage, create fear or kill is a wide spread and rapidly escalating social phenomenon in Nigeria, that poses enormous security challenges for the country. He further explained that violence could manifest as an organized group action which progressively escalate into a sustained activity which subsequently engulf much of a community, state, geographical zone or a country.

From another perspective, Babalola, (2013) opines that violence has been described as the unlawful use of forces and the exercise of an instance of physical force. Scholars like Obasi, (2013), Salomon, (2002) have identified various types or groups of violence, for instance, Obasi, (2013) has group violence into eight board categories based largely on the target. They include; general violence, sexual violence, domestic violence, school violence, cult violence, communal violence, ethnic violence and religious violence. On the other hand, Salomon, (2002) and Dupuy, (2008) have noted that violence implies both the direct and the structural aspects. For example direct violence includes personal assault, rape, brutality, terrorism, murder, ethnic cleansing, institutional war, state sponsored terror, industrial destruction of plants and animals. On the other hand, indirect violence is characterized by sexism, racism, discrimination, poverty, lack of education and health services.

Several factors are responsible for the violence that has engulfed Nigeria. For instance, Gyot, and Ali, (2013) have noted that selfishness, injustice, greed, dishonesty, loss of moral values in the society, oil theft in the Niger Delta region among others are the major causes of conflict. Other causes of violence in Nigeria include corruption, religious fanaticism, ethnicity, negative tribal political/electoral tendencies, abject poverty, hunger, illiteracy and unemployment in the country. There is also the exploitation of the weak and the unenlightened who cannot analyze issues critically. Most of our politicians cut corners to get to the top of their career. Indeed almost all the cities in Nigeria have experienced one form of conflict, crisis, strife violence or the other. For example the Niger Delta militancy of 2000s to the Boko Haram attacks of the 2010s. Besides where such violence is sustained, they retard all facets of national development and possibly lead to the disintegration of the country. From the foregoing exposition on the nature and degree of conflicts and violence in Nigeria, the contention of this paper is that a 
peaceful society can still be achieved in the country through peace education. In other words, citizens need to know what causes conflicts, how conflicts can be monitored, prevented, managed and resolved without allowing them to deteriorate into violence.

\section{The Concept of Peace}

Peace as a concept has been variously defined. According to UNESCO (1999) declaration, 'peace is in the mind of men'. The UNESCO Director General cited in Haliru, (2013) noted that the term peace simply denotes the state of calmness. It also refers to relationship characterized by respect, appreciation of difference and justice. Hick (1988) has opined that peace is more than the absence of war. It is living together with differences of sex, race, language, religion or culture, while furthering universal respect for justice and human rights on which co-existence depends.

In some circles, peace is equated with harmony. In this sense, there is hardly any friction among people that sum up a given society. This view however seems utopian as any community can hardly exist without one form of friction or the other. In another sense as Rinji, and Yiben, (2005) have noted, peace is seen as order, which signifies the absence of war. They further argued that once there are no wars, peace is said to reign especially in volatile society like ours. In essence it may be argued that when there are no ethnic conflicts, religious crises, labour demonstrations and so on, order is said to exist and therefore there is peaceful co-existence.

The issue of peace has gained attention all around the world. There are many inspiring programmes and actions witnessed collectively which show that there is a global yearning for peace. This no doubt necessitated the United Nations to declare the year 2000 as the international year for the culture of peace.

The question then is how can peace be cultivated in the minds of men especially in Nigeria. In this regard, Osaat, Orlukwu, and lyleka-Jaja, (2018) argues that when the culture of peace is imbibed by the citizenry, other positive aspects like national unity, cohesion, inter-ethnic and religious co-existence and economic development naturally follow. Peace education therefore is capable of enhancing the culture of peace, thereby making room for dialogue, negotiation, and peace mediation. What then is peace education?

\section{Peace Education}

The origin of peace education is as old as mankind itself. However the formation of the United Nations (UN) in 1945 after the Second World War provided a stimulus for the rigorous and systematic approaches to the study of peace and conflict resolutions across the globe (Ramsbotham, and Miall, 2016). Peace education as the National Open University of Nigeria, (2010) has noted, first began in the United States of America (USA), Canada, some European countries and Japan. Today hundreds of courses related to peace education have been offered at various universities in those countries. With the current wave of violent extremism in the world and in Nigeria, Peace Education and Peace and Conflict Resolution become more necessary. It is in this regard that the course (PCR) in Nigeria universities and several other higher institutions of learning becomes necessary (Abbas, 2018).

Peace education according to UNICEF (1999) refers to the process of promoting the knowledge, skills, attitudes and values needed to bring about behaviours change that will enable children, youth and adults to prevent conflict and violence both overt and structural to resolve conflicts. From another perspective, Schmidt, (2006) stresses that peace education is about empowering people with skills, attitudes and knowledge to build, maintain and restore relationships at all levels of human interactions and to build a sustainable environment and protect it from exploitation and war. For Ikwumelu, (2010) peace education engages the students in three major roles; firstly, it inculcates relevant knowledge, skills and attitudes in relation to non-violence. Secondly, it spurs the student into personal action using the acquired knowledge, skills and attitudes to establish non-violent structure, and finally to protect the environment/society from wars or conflicts.

Peace education in essence is based on a philosophy that teaches non-violence, love, compassion, trust, fairness, cooperation and reverence for human life on our planet. It is about empowering people with skills, attitudes, knowledge:

- $\quad$ To build, maintain, and restore relationship at all levels of human interactions

- To develop positive approaches towards dealing with conflicts from the personal to the international levels.

- To create safe world based on justice and human rights.

- To create safe environments both physical and emotionally that nurture each individual.

- $\quad$ To build a sustainable environment and protect it from exploitation and war (Harris and Synott, 2002: 3-6).

There is no agreement among scholars as to what peace education means. It is in this connection that Dupuy, (2008:27) states that, "there is no uniform concept of peace education and the international discourse on this topic is still in its infancy". He further posits that for a shared and clearer understanding to be achieved, the various socio-economic, political, historical and cultural contexts must be taken into account. This stems from the fact that there is differing emphasis on peace education programmes. According to Salomon, (2002) regions of relative tranquility stress education for cooperation and harmony, thereby promoting the idea of general culture of peace, whereas regions of conflict emphasize education for violence prevention. 
From the foregoing discussion on peace education, it can be summarized as efforts to promote peace, especially in conflicts or violence-ridden areas through educational activities. It also aims at ameliorating the escalating level of violence in various forms so that individuals can live and work in a relatively peaceful atmosphere that could ultimately engender a global culture of peace.

\section{Strategies already put in place for Peace Education in Nigeria}

In this section of the study, we shall discuss the various strategies to peace education in Nigeria. Firstly, it has been observed that there have long been elements of peace education in the informal indigenous system of education in Nigeria. These centers and emphasize, character training, peaceful co-existence and respect of other people's opinion. Although the nomenclature of peace education was not well stated in this system of education, yet traditional proverbs, folk stories and songs were frequently used to teach values that built positive relations in the community. It is in this regard, that Emmanuel, (2004) has opined that there are other socializing agents in the society; the mass media, the National Orientation Agency (NOA) programmes, the non-governmental organization interventions, parents, religious bodies and opinion leaders among other platforms have constantly called for peace in form of workshops, seminars, sermons, and conferences. Despite these efforts, it does not appear that conflicts, violence and insecurity are abating. This is a signal that we need to do more than sermonizing to bring sustainable peace to our society.

Secondly, considering the complexities and nature of peace as an indispensable condition in human relationship, Nigerian government has set in motion an education programme aimed at introducing issues concerning peace in the curriculum of the basic education in form of peace education. This is in conjunction with the constitutional provisions prescribing peace related education as an instrument for national integration (Federal Republic of Nigeria, 1999). Peace studies in this sense as Olusegun, (2014) has opined rejects a silo model of comprehending the world, instead, it embraces interrelated and interdependent knowledge, scholarship and interpretation from all disciplines. As such it epitomizes the potential for students to learn peace culture across disciplines and across the curriculum.

This however, in the past had taken various forms such as citizenship education, global education, civic education and social studies. In 2006 for instance the Nigeria Education Research Development Council (NERDC) produced the 9-year basic education programme which reviewed and re-aligned the existing primary and junior secondary school curriculum. The new social studies curriculum now incorporates contemporary issues like peace and conflict issues, child, women trafficking, youth restiveness etc. While a new civic education curriculum was disarticulated from the new social studies curriculum, other energizing areas like peace education, gender education, and family life education were integrated into the social studies curriculum. This restructuring in the curriculum is in the effort to expose young Nigerians to elements of peace education. However, Olusegun, (2014) is of the opinion that peace education has not succeeded much in the school curriculum because while bits of peace education can be seen in school subjects like social studies, history, religious studies, civic education and moral education, these aspects are not significant enough for achieving the goal of the entire peace education programme. In other words, peace education should be a subject of its own.

The tertiary level of education in Nigeria is not left out in the quest for peace in the country. Abbas, (2018) has noted that since after the civil war, Nigeria has attempted to build a sense of social cohesion and togetherness amongst its diverse population. One standout scheme is the National Youth Service Corps (NYSC) which is a mandatory one-year national service for graduates from Nigerian universities. The graduates are often transferred to a state other than theirs to learn and boost understanding of others' cultures and life experiences. Although the scheme has been maligned by many due to its many shortcomings it has achieved some measure of peace in the country. Efforts should however be made to remove the bottle necks in the programme.

Another attempt at national integration and peace is the introduction of peace and conflict studies/ peace and conflict resolution in Nigeria universities and other specialized institutions. Over the years Nigeria's universities as Dupuy, (2008), Abbas, (2018), Obasi, (2013), Olusegun, (2014) have noted, started offering courses in international studies and diplomacy, security studies and eventually peace and conflict studies or Peace and Conflict Resolution (PCR) as it is often called is an inter-disciplinary field of study aimed at analyzing, preventing, de-escalating and solution providing to conflicts and violence by peaceful means by seeking for all parties involved in any given conflict (Abbas, 2018).

Peace and conflict studies as being taught in the tertiary institutions of learning therefore identifies and analyses violent and non-violent behaviours and the structural mechanisms fuelling social, political and economic conflicts with a view towards understanding those processes which lead to a more desirable human condition. Nigerian universities and institutes that offer peace and conflict studies as Abosede, Okon, and Effiong, (2014) have noted include; the university of Ibadan, the centre for conflict management and peace studies at universities of Jos, the centre for peace, diplomatic and development studies (CPDSS) at the university of Maiduguri, Borno state, University of Nigeria Nsukka, the universities of Ilorin and Port-Harcourt and the National Open University of Nigeria (NOUN) among others. In addition, there are Research Institutes focusing on peace and conflict issues 
in Nigeria. They include; the institute for peace and conflict resolution under the auspices of Nigeria's Ministry of Foreign Affairs. Another independent institute on peace and conflict studies is the Abdulsalami Abubakar Institute for Peace and Sustainable Development (AAOPSDS). Some private universities in Nigeria like; Babalola University Ado-Ekiti and Landmark University in Kwara State also offer undergraduate courses in peace and conflict studies. A similar trend in these higher institutions and institutes offering (PCS) is that some of them do not offer full fledged degree programmes yet. Rather they offer Professional Diploma in Peace and Development Studies, post graduate diplomas, master's degrees. They also conduct research on issues bothering on peace and security in Nigeria and on the continent, as well as serving as a think-tank and an agency to strengthen Nigeria's capacity for the promotion of peace and conflict prevention, management and resolution among others (Salomon, 2002). From the foregoing discussion it is evident that there are diverse strategies put in place for peace education in Nigeria. In other words both the Nigerian government, private organizations and social institutions in Nigeria are interested in peace education.

\section{New Strategies That Can Be Adopted in Peace Education in Nigeria}

In this section of the paper, new strategies have been suggested to strengthen the existing strategies on ground to address the issue of peace education and national cohesion in Nigeria. They include the following:

i) In promoting peaceful co-existence and religious tolerance, the education planners should include peace education to the school curriculum. This should start from the primary school age so as to get the young minds while they are still innocent. The earlier the Nigerian child imbibes peace culture the better for this nation. To this end, supplementary readers and reading comprehension passages in basic education should be in such a way that peace culture would be emphasized.

ii) While students are in schools, every effort should be made by the teachers and school administrators to make them love and cherish each other. This brings about unity and love amongst them even when they leave school and join the larger society such unity and love is important for national development. In essence, in Nigeria we need education that can psychologize individuals to respect the life of other people they live with. Such education should develop critical thinking in our youths. Osaat, Orlukwu, and lyleka-Jaja, (2018) has noted that most of the conflicts witnessed in the country stem from ignorance and illiteracy. When the masses are educated, it inculcates in them the spirit of sharing ideas, listening to one another, and respecting other people's views and opinions.

iii) There is an urgent need to conduct experiments and researches from which instructive solutions could be found in these conflicts and crises. The government should adequately fund such researches. For instance, the usual militarization of crises where the use of police and military peacekeeping is the vogue, could manifest some level of calmness in our environment, the populace may not completely live in peace. The use of brutal force to remedy such conflicts should be cautiously done to avoid provoking greater political, religious, ethnic or tribal backlash. Reform is also needed in military strategy to deal with civil domestic security situations especially when current rotational system often puts military officers from different parts of the country into local situations that they may not have the cultural sensitivity to manage.

iv) Policy attention should also be directed to teacher training programmes with conflict resolution techniques as part of their programme and curriculum in all higher institutions especially military and police training institutions. This is because one cannot give what he himself does not know or have. It is when the teachers are knowledgeable in peace education that those under them would benefit. In a school situation for instance, whereby students are flogged or given one punishment or the other as a result of conflicts should be discourage by peace education. This is because punishment brings negative results to the course of peace education. It sends negative signals, like hatred, dislike, malice, repulsion in the minds of students. Instead, dialogue, should be used.

v) The government should through the ministry of education and NGOs organize seminars, workshops, discussion forums with more focus on non-violence, conflict resolutions, tolerance, coexistence, and peace culture among others. In addition, the culture of get rich quick in Nigeria society should be seriously redirected towards human value where humans would empathize with their fellow humans and tolerate each person's dissimilarities. All forms of malice, hurts, offences and pains in the past should remain in the past.

vi) Government policies and programmes should be based on the principles of justice and fair play. Similarly, human rights should be implemented in Nigeria for the enthronement of peace and unity in the society. The various issue of marginalization across the country should be seriously looked into and redressed. Among them is the issue of unemployment among the youths. These idle youths readily fall prey to politicians who use them to ferment troubles and violence in the society.

\section{Conclusion}

It is the contention of this paper that no society can really attain its economic and political heights when the ingredients of peace and unity are lacking. There is thus the need for Nigerians to continue to strategize on peace 
education until lasting peace is achieved. Moreover, it is suggested that the golden rule should be observed and we should all toe the path of peace.

\section{References}

Abass, A.I. (2018). Peace and conflict resolution in Nigeria: An imperative tool for countering violent extremism. A paper presented at the conference of Nigerian Political Science Association (NPSA) North East Zone. Federal University Kashere.

Abosede, A.U., Okon, E.E. \& Effiong, C. (2014). Conflict management: The Nigerian government's strategies and the question of enduring peace. Business and management research, Vol. 3. No. 2, 2014.

Babalola O. (2013) Combating Violent-Extremism and Insurgency in Nigeria: A Case Study of the Boko Haram Scourge.

Chandra, S. (2016). Promoting global peace and civil engineering through education. http://www.igi-global.com.

Dupuy, K. (2008). Education for peace: building peace and transforming armed conflict through educational systems. Oslo; International Peace Research Institute.

Emmanuel, M.A. (2004). Peace education as a Panacea for achieving goals of education for all in Nigeria. International Journal of Literacy Education (UNESCO) Chair Publication Vol. 2, No. 1, June, 2004.

Federal Republic of Nigeria (1998). National Policy on Education, Lagos: NERDC Press

Ghandi, M.K. (2016). Conflict and violence. https://www.google.com.ng. Retrieved 10/11/2018.

Gyot, B.F. \& Ali A.I. (2013). Peace education and national and national development: The Nigeria experience in annual book of reading (PEAN) Nigeria.

Haliru, U. (2013). The need for peace education in Nigerian secondary school curriculum in Nigeria. Journal of Education Philosophy, Vol. 24, No. 1, October, 2013.

Harris, I. \& Synott, J. (2002). 'Peace education for a new century' social alternatives, 21(1) 3-6.

Ikwumelu, S.N. (2010) Constraints to Institutionalization of Peace Education in Nigeria Educational System. Nigerian journal of Social Studies. Vol XIII (1\&2) $204-212$

Kreitner, R., \& Kinicki, A. (2010). Organisational behaviour 9th ed., New York: Irwin/ McGraw-Hill

Obasi, E. (2013). Understanding violence in Nigeria with implications for education in Nigeria. Journal of Sociology of Education, Vii(1),

Olusegun, O.O. (2014). Peace education a means of attaining millennium development goals in Nigeria. Nigerian Journal of Sociology of Education (NJSE), Viii(1),

Osaat, S.D., Orlukwu, A.E. \& Iyieka-Jaja, J.I. (2018).Engineering research and innovation in peace education. Nigeria Journal of Educational Philosophy, 22(2).

Ramsbotham, O.W. \& Miall, I.I. (2016). Contemporary conflict resolution in (YSU) readings in general studies, Yobe State University.

Rinji, D.N. \& Yiben, J.J. (2005). Language education as a parameter for peace and stability of Nigeria. Nation. Jos, Wais Press.

Robbins, S.P. \& Judge, T.A. (2010). Organizational behaviour, $14^{\text {th }}$ edition New Delhi, Prentice Hall.

Salisu, R.L. \& Sadiq, M.A. (2013).The role of education in conflict management, peace democracy in Nigeria in book of reading, PEAN, Nigeria.

Salomon, F. (2002). Peace education: The concept, principles and practices in the world. Mahwah, N.J. Lawrence.

Schmidt, F. (2006). Peace education theory. www.peace.cap/peace education thumerournaly.html.

UNESCO (1999). Culture of peace (n.d). retrieved from www.unescoculture of peace html on $6^{\text {th }}$ Nov. 2018.

UNICEF (1999) Peace Education in UNICEF. Working Paper Education Section programme Division UNICEF New York. 